DOI: 10.46340/ephd.2021.7.3.17

\author{
Anatolii Vovk \\ ORCID ID: https://orcid.org/0000-0002-3636-3773 \\ National University of Life and Environmental Sciences of Ukraine, \\ Kyiv, Ukraine
}

\title{
PHILOSOPHICAL METHODOLOGY OF VOLODYMYR SHYNKARUK
}

\author{
Анатолій Вовк \\ Національний університет біоресурсів і природокористування України, \\ м. Київ, Україна
}

\section{ФІЛОСОФСЬКА МЕТОДОЛОГІЯ ВОЛОДИМИРА ШИНКАРУКА}

The article analyzes the main features of the philosophical methodology of Volodymyr Shynkaruk. The hermeneutic method was used to analyze the texts expressing the teachings of Volodymyr Shynkaruk on the methodology of philosophical and scientific thinking. To explain the nature of this doctrine, a comparative analysis was used, in particular, the views of Volodymyr Shynkaruk were compared with the ideas of Pavel Kopnin's philosophical and scientific methodology. Dialectics became a philosophical method for Volodymyr Shynkaruk. When applied to anthropology, dialectics has made it possible to show a man as the unity of opposites, because in each individual there is opposition and unity of social and biological, individual and universal. Acceptance of the meanings created by previous generations at the beginning of personality development allows adding own meanings later thanks to individual creativity. Assimilation and production of meanings are not formal-logical, and this encourages the development of hermeneutics. For dialectics, the greatest anthropological opposites are manifested in the fact that human cognition is recognized as the unity of the formal-logical and intuitive-hypothetical. The functioning of the second intuitive-hypothetical element of cognition and its unity with the formal-logical are the subjects of hermeneutics. Concrete-historical interpretation of categories becomes the main element for deepening knowledge. The more knowledge of categories a scientist has, the deeper he knows reality. And more knowledge of reality allows you to better understand the meaning of categories. This creates an openness to new knowledge, to acts of understanding, in which knowledge is manifested as art, and not only as a formal procedure. The transition to understanding the categories of dialectical materialism seemed quite natural, not only from the standpoint that they function as a reflection of the general properties of objective reality or as general concepts of thinking, but also from the standpoint that these categories function as general concepts of culture. In culture, these categories are not only concepts but act as units of meaning, which include, inter alia, metaphorical meanings and culturally formed anthropologists. Accordingly, such an interpretation of categories as phenomena of cultural thinking is important for the then growing transformation of dialectical materialism into the art of hermeneutics. Interpretation by philosophy of the finished results of scientific knowledge presupposed confidence in the provisions, which have not yet been proven but are assumed by the general worldview. The above approach allowed us to interpret the philosophical achievements achieved by the representatives of theoretical physics because theoretical physics itself did not always proclaim exactly the results that were most consistent with philosophical and dialectical materialism. Only a philosophical reinterpretation of the scientific worldview made it possible to reconcile certain scientific and ideological theories with the provisions of classical dialectical materialism.

Keywords: history of philosophy in Ukraine, modern Ukrainian philosophy, philosophy of Volodymyr Shynkaruk, Kyiv anthropological school, dialectical materialism, anthropology, hermeneutics. 
Постановка проблеми. Сьогодні загальною стала тенденція інтерпретувати філософські, антропологічні ідеї Володимира Шинкарука через аналогії, через наявність схожих ідей у низці подібних різноманітних концепцій. Це підміняє спосіб знаходження місця цих ідей в системі самого Володимира Шинкарука i їх пояснення в світлі його філософської системи. Згідно з одними сучасними інтерпретаторами, виявляється, що власної ідейної філософської системи Володимира Шинкарука не існувало, а була загальна радянська філософія як система, по відношенню до якої Шинкарук здійснював критику, реконструкцію, часткові зміни, слідом за своїм вчителем Павлом Копніним. Інші історики філософії намагаються довести, що Володимир Шинкарук створив оригінальне вчення про світогляд і людину, відійшовши від матеріалістичної діалектики.

Актуальність. Аналіз філософської методології Володимира Шинкарука може відкрити шлях до об'єктивної історико-філософської інтерпретації всієї його філософії. Це дасть можливість дати відповідь на питання про межі застосування ідей Шинкарука в сучасних філософських дискусіях.

Мета статті - аналіз основних рис філософської методології Володимира Шинкарука.

Методи дослідження: для аналізу текстів, що виражають вчення Володимира Шинкарука про методологію філософського і наукового мислення застосовано герменевтичний метод. Для пояснення характеру цього вчення застосовано порівняльний (компаративний) аналіз, зокрема здійснено співставлення поглядів Володимира Шинкарука з ідеями про філософську і наукову методологію Павла Копніна.

Ступінь дослідження, аналіз останніх публікацій. Спроби тлумачення філософської методології Шинкарука часто $\epsilon$ певним викривленням, яке передбачає, що, нібито, змагаються дві вічні філософії: західна традиція філософування (від самих початків і до сучасних феноменології, екзистенціалізму, позитивізму), з одного боку, і своєрідна псевдовічна матеріалістична філософія (радянська філософія), з іншого боку. Вважалося, що в цьому протистоянні роль Володимира Шинкарука і Павла Копніна полягала в тому, що вони руйнували цю “псевдовічну” філософію і переходили на бік “вічноі” традиції філософування" .

Така схема, безумовно, є величезним спрощенням, оскільки у Павла Копніна і у Володимира Шинкарука існували власні філософські системи, які були оригінальними. Дані системи, звісно, протистояли радянському офіційному марксизму, мали від нього важливі відхилення, але це не означає, що вони відразу ставали частиною “вічної” західної філософії. Перевагами філософських систем Копніна і Шинкарука вважається те, що їхні ідеї є аналогічними до якихось ідей західних дослідників, чи класиків філософіїㄹ․ Цей підхід має право на існування, але через аналогії доведення не відбувається. В історико-філософській роботі аналогія може продукувати певні робочі гіпотези. Але доведення повинне відбуватися через дослідження текстів, вивчення біографії філософів, через побудову, власне, наукових теорій і їх подальшого підтвердження щодо конкретних способів інтерпретацій філософських праць.

Якщо інтерпретувати тексти просто через аналогії, то, відповідно, можна досягти будь-яких результатів, які в подальшому не витримають процедури верифікації. Тому досліднику необхідно підходити виважено і висувати в інтерпретації філософських ідей Володимира Шинкарука виключно ті гіпотези, що можуть бути підтверджені текстами; що не виходять за межі текстів; які можуть бути доведені у подальшій перевірці при вивченні всього корпусу праць Володимира Шинкарука, всієі його думки в її конкретно-історичній втіленості і в її світоглядній еволюції.

Виклад основного матеріалу та результатів дослідження. Основним методом філософії у марксизмі проголошувалася діалектика. Слід зауважити, що діалектика осмислювалася як вчення про єдність i боротьбу протилежностей. Діалектика вчить про необхідність виокремлення протилежностей у кожній об'єктивній реальності, вивчення їх боротьби та єдності в цій реальності. Діалектика, в першу чергу, розумілася як теорія про протилежності та їхню єдність, які належать самим об’єктам. При цьому, постійно підкреслювалося, що протилежності, які існують в об'єктах, $\epsilon$ сутнісними. Відповідно, не потрібно було добирати штучних прикладів для ілюстрації єдності і боротьби протилежностей, а необхідно просто вміти скрізь вбачати ту чи іншу сутнісну протилежність.

Найбільш помітним чином єдність і боротьба протилежностей виявляється у високорозвиненій матерії, що розвивається і рухається. Суспільство вважалося високорозвиненою матерією такого

\footnotetext{
${ }^{1}$ Табачковський, В. (2002). У пошуках невтраченого часу. Київ: Парапан, 65.

2 Там само, 62.
} 
типу. Але, звісно, єдність та боротьба протилежностей виявлялася і в самій структурі природи, в людині. Людина, в цілому, постає як єдність і боротьба протилежностей. Вона постає як єдність біологічного і соціального, інстинктивного і розумного, вольового. У ній існують певні суперечності, протистояння; особливо важливою стала єдність необхідності і свободи.

Формування діалектичного вчення про людину стало базисом для появи специфічного гуманізму. Визнання єдності і боротьби протилежностей ріднило дану філософію з німецькою класичною філософією та відкривало шлях в антропології для більш глибокого розуміння суперечливостей людського існування.

Також варто зауважити, що діалектика розумілася як метод пізнання, який найбільш повно відображає специфіку людського мислення. Чим глибше сягає людське мислення в пізнанні, тим більшою мірою воно є діалектичним. Особливо необхідною $є$ діалектика в процесі творчого пізнання. Процес творчого наукового пізнання поєднує в собі елементи формально-логічного і інтуїтивного мислення. Відтак, саме мислення постає як єдність протилежностей.

Якщо мова йшла про усталені наукові знання, оформлення знань в систему, виведення конкретних знань із загальних, то визнавалася правомірність застосування формальної логіки. Формальна логіка не заперечувалася у своїх правах. Наголошувалося лише на тому, що існують певні обмеження щодо іiї застосування. Якщо ж заперечувати діалектику і висувати формальну логіку як універсальний метод, який дозволяв би не лише структурувати знання, добувати певні пізнання, але й приписував би певну онтологічну структуру самій дійсності, виводив 3 цього певну онтологію, то логіка набула би всіх рис метафізики ${ }^{1}$ Ц Цей висновок $є$ цілком правильним, адже нам відомо, що до цього часу існують певні метафізичні концепції, приміром, неотомістичні, які намагаються використати формальну логіку, ті iї закони, які визнавав ще Аристотель, і розглядати їх як закони самого буття. Діалектика вказує на те, що буття є набагато складнішим. Закони формальної логіки діють у певних межах. Але пильний погляд на дійсність переконує нас в тому, що більш адекватними для цієї реальності є закони діалектики, особливо, якщо перед нами постає певний розвиток.

Важливо, що діалектика мислиться Шинкаруком як філософський мета-метод. Його застосування до конкретних наук є можливим переважно при уточненні змісту категорій діалектики. Необхідно, по-перше, виокремити категорії, які застосовувалися в історії діалектики; сформувати систему категорій; показати яким чином можливе поглиблення змісту традиційних і виокремлення нових категорій. Важливо, що застосування основних, класичних категорій з додаванням нових повинно протистояти спробам сцієнтизації філософіїㄹ․ Оскільки, певні категорії, які мають обмежене значення в науках $\mathrm{i} \epsilon$ просто найбільш загальними поняттями окремих наук, видаються продуктивними і можуть пояснювати розвиток, існує тенденція застосування цих понять до філософії і набуття ними статусу філософських теорій. Приміром, так діють прихильники синергетики. Теорії розвитку та певні концепти, які синергетика пропонує, з точки зору діалектичної методології, $\epsilon$ правомірними в межах фізики і не можуть переноситися у сферу дослідження соціуму. Саме такою $€$ позиція Шинкарука, принаймні у радянський період. Ця позиція цілком суголосна з роздумами Копніна, який теж заперечував правомірність переносу понять окремих наук у філософію та використання цих понять для заміни філософських категорій. Філософські поняття мають відображати кожен новий рівень розвитку науки, i тому необхідним $є$ оновлення всього категоріального апарату діалектики і навіть нове розуміння законів діалектики, але не механічне перенесення понять чи «законів» 3 конкретних наук у філософію.

Важливо, що діалектика сама по собі виступає по-перше онтологією, або вченням про все існуюче; по-друге, є гносеологією, вченням про пізнання; по-третє - основою для соціології․․ Звісно, що онтологію, гносеологію та соціологію можна було б розглядати як окремі вчення про буття, матерію, про пізнання і соціум. Але для Павла Копніна та Володимира Шинкарука важливо було об’єднати всі ці сторони діалектики в єдину систему наукової діалектики. Подібна позиція була характерна для класиків марксизму, ленінізму.

На переконання представників Київської філософської школи, діалектика вирізняється всезагальним характером і може виступати універсальною методологією для розуміння будь-якої реальності. Передбачалося, що діалектика виявляє закони, характерні для самої дійсності. Основні риси цієї дійсності “схоплюються” і фіксуються в категоріях. Що більше ми уточнюємо смисл категорій,

\footnotetext{
${ }^{1}$ Шинкарук, В. (1977). Единство диалектики, логики и теории познания. Киев: Наукова думка, 271.

${ }^{2}$ Копнин, П. (1973). Диалектика, логика, наука. Москва: Наука, 87.

3 Там само, 40-57.
} 
глибше їх розуміємо, тим у більшій мірі ми можемо збагнути дійсність. Своєю чергою, нове пізнання дійсності дозволяє більш повно сформувати уявлення про категорії. Процеси інтенсивного прояснення сенсу категорій та все більш глибоке пізнання дійсності є взаємозалежними.

Таке співвідношення між категоріями і дійсністю показує, що у тогочасній філософській думці формувалася тенденція до герменевтичного розуміння пізнавальної діяльності. Адже діалектика, спрямована почергово на грунтовне розуміння всієї системи категорій і на поглиблене осягнення самої дійсності та іï суттєвих властивостей являє собою певне герменевтичне коло. Пізнання покликане рухатися за цим герменевтичним колом. Повне, всебічне розуміння дійсності, в результаті експериментів, висування гіпотез, підтвердження цих гіпотез - це один напрям руху. Інший напрям руху за герменевтичним колом репрезентує розвиток культури мислення науковця; розвиток його розуміння змісту всіх загальних категорій, їх співвідношення; включення науковцем знань, отриманих, або в результаті емпіричних досліджень, або в результаті формування припущення та верифікації певних гіпотез у своє пізнання; подальша їх обробка за допомогою категорій, які $€$ в свідомості науковця - всі ці моменти сприяють більш грунтовному і всебічному розумінню власних конкретних знань у певній науковій галузі і, водночас, глибшому осягненню дійсності.

Слід звернути увагу на те, що Володимир Шинкарук і Павло Копнін не стверджували, що краще пізнання філософських категорій дозволить досягти більшої кількості наукових знань при поверненні до предметів дослідження, до живої реальності, яка досліджується. Філософи добре усвідомлювали необов'язковий характер даної взаємозалежності. Інтенсивне розширення знань відбувається за рахунок примноження емпіричних знань $\mathrm{i}$ воно передбачає діяльність науковця як експериментатора чи теоретика, що висуває гіпотези. Водночас, філософська культура науковця дозволяє глибше зрозуміти ті реальності, які вже пізнані, завдяки звичайній науковій діяльності експериментатора чи теоретика. Йдеться про те, що, з одного боку, інтенсивність знань зростає, оскільки науковець, як культурна особистість, як представник наукової спільноти інтенсивно розширює свої пізнання. А, з іншого боку, науковець, як філософськи освічена людина, може поглибити свої пізнання. Тут доречно навести приклад з Вернером Гейзенбергом. Як науковець він розробляє певні теорії у квантовій фізиці, а як філософ він може пропонувати онтологію, яка б узгоджувалася з його квантовими теоріями. Також Гейзенберг зміг показувати місце онтології в історії філософії, історії культури, історії математики, історії фізики, з позиції певного світогляду. Гейзенберг з успіхом реалізує даний проект у цілій низці своїх робіт.

Вищеозначений підхід дозволяв Шинкаруку філософськи інтерпретувати набутки, яких досягали представники теоретичної фізики, оскільки сама теоретична фізика не завжди проголошувала саме такі результати, які були б найбільш суголосними 3 філософським і 3 діалектичним матеріалізмом. Лише філософська переінтерпретація наукового світогляду дозволяла узгоджувати певні наукові і світоглядні теорії з положеннями класичного діалектичного матеріалізму.

Наприклад, класичним для діалектичного матеріалізму було твердження про те, що всесвіт $\epsilon$ безкінечним, причому, у різних відношеннях: в просторі, у часі, у невичерпності внутрішнього складу атома. Сучасна наука довела, що ділення матерії відбувається надзвичайно інтенсивно, але не безкінечно. Ще в 1920-ті роки було доведено, що всесвіт не є безкінечним у просторі і часі. Філософи, намагаючись знайти вихід із цієї ситуації, всіляко підтримували ті побудови теоретичної фізики, які підкреслювали, що до великого вибуху існували інші стани всесвіту; пропонували прийняти теорії періодично існуючого всесвіту; або говорили про те, що існує більш складний, багатовимірний всесвіт (наприклад, теорія академіка Зейдельмана розглядала наш всесвіт як відгалуження на цілому “дереві всесвітів”). Подібні спекуляції не завжди підтверджувалися емпірично, а тому вагоме значення мала наявність у науковців і філософів певних переконань, і також віри у ці переконання. Деякі гіпотези виявлялися надзвичайно важливими для всього характеру діалектики, адже це було ядро положень класичного матеріалізму марксистсько-ленінського типу і філософам необхідно було якимось чином дійти цих положень, беручи за основу науковий базис.

Безумовно, Володимир Шинкарук і Павло Копнін відчували свою правоту в тому відношенні, що в своій критиці матеріалізму представники тогочасного ідеалізму значно перебільшували розрив між сучасною їм наукою і положеннями класичної матеріалістичної діалектики. Дивлячись на ці перебільшення, філософи Київської школи намагалися спростувати думки, які були в ідеалізмі, i довести повну когерентність між принципами діалектичного матеріалізму та тогочасною наукою, особливо, фізикою. Як ми вже зазначали, це вдавалося, за рахунок того, що ціла низка реальностей 
насправді розумілася не таким чином, як вони представлені у фізиці, а репрезентувалася у більш глибокій філософській інтерпретації. У цій ситуації матеріалістична діалектика виступала своєрідним герменевтичним апаратом, який дозволяв перетлумачувати наукову картину світу у вигідному для діалектичного матеріалізму руслі. Таке перетлумачення призводило до того, що філософія тяжіла до герменевтики i, більшою мірою, виступала як мистецтво тлумачення, що доповнювало попередню аналітичну роботу.

Звідси, цілком природним виглядав перехід до осмислення категорій діалектичного матеріалізму не лише з позиції того, що вони функціонують як відображення загальних властивостей об’єктивної дійсності або як загальні поняття мислення, але й з тієї позиції, що ці категорії функціонують як загальні концепти культури. У культурі ці категорії $є$ не лише поняттями, а виступають одиницями смислу, які включають у себе, з поміж іншого, метафоричні сенси та культурно-сформовані антропологеми. Відповідно, таке тлумачення категорій як феноменів культурного мислення $\epsilon$ важливим для тодішнього все більшого перетворення діалектичного матеріалізму в мистецтво герменевтики.

Даний процес, також обумовлювався поступовою трансформацією діалектичної логіки у методологію науки та логіку наукового дослідження. В цьому контексті, діалектична логіка фактично виступає герменевтичним мистецтвом, що було покликане інтерпретувати результати філософії науки та філософських методологій наукових досліджень. Діалектична логіка була покликана виявляти те, яким чином і за допомогою яких категорій відбувається пізнання, які процеси сприяють його поглибленню. Логіка наукових досліджень як філософія науки це дозволяла зробити. Ы діалектичний матеріалізм як вчення про категорії, надавав світоглядне та культурно-історичне узагальнення тому матеріалізму, що репрезентувала логіка наукових досліджень.

Цілком закономірно, що в київській філософській школі вивчався вплив системи категорій на процес наукового пізнання, на результати наукового пізнання, на розвиток наукових теорій i на процеси їх поглиблення, на суб'єкт наукового дослідження під час самого дослідження. Адже, окрім загальних закономірностей, що вимагають віри для того, щоб продовжувати наукове пізнання, дотримання власної гіпотези під час наукового дослідження, пошуку доказів та емпіричних даних на користь конкретної гіпотези, необхідна ще й певна загальна культура. Ця загальна культура науковця проявляється у поглибленому розумінні філософських категорій.

Весь процес освіти, виховання покликаний, власне, до того, щоб формувати у суб'єкта наукового пізнання загальну культуру, яка дозволила б поглиблено розуміти категорії i співвідношення між ними не лише у формально-логічному, діалектичному ключі, але й в аспекті їх культурного втілення, культурного функціонування, культурної єдності цих категорій. Розробка даної проблематики була надзвичайно важливою для Павла Копніна i Володимира Шинкарука. В подальшому їхні напрацювання розвивалися, завдяки Сергію Кримському, Мирославу Поповичу, Євгену Бистрицькому та іншим мислителям Київської філософсько-антропологічної школи.

Для Володимира Шинкарука яскравим прикладом філософа, що використовував категорії у єдності з історією культури, з історією духовності, з історією усього людства став Гегель, оскільки Гегель розглядав суб'єкт пізнання не лише як окрему особистість, яка спирається на апріорні категорії, що існують у їі індивідуальній свідомості ${ }^{1}$. Суб'єкт пізнання поставав для німецького мислителя як модерна людина, що, в певному розумінні, являє собою все людство, втілює в собі культуру всього людства, категорії якої $є$ квінтесенцією всього попереднього духовного розвитку людства ${ }^{2}$. Через освіту, виховання, пізнання людина повторює той шлях, який історично пройшло все людство у пізнанні категорій (у науковому і філософському пізнанні) i приходить до певних результатів, що мають характер культурного синтезу, а не $\epsilon$ лише результатом певного пізнавального підсумку тут і сьогодні.

Без сумніву, Гегель зобразив процес функціонування надбань попередньої культури ідеалістично: в кожному окремому сучасному суб'єкті функціонує абсолютний суб'єкт - абсолютний дух, який зміг проявитися через всю попередню історію людської духовності, в часи Гегеля він функціонує вже на рівні максимального прояву.

Важливо, що ніякого подібного абсолютного духу, абсолютного суб'єкта Володимир Шинкарук не міг репрезентувати у власній діалектично-матеріалістичній системі. В існування

\footnotetext{
${ }^{1}$ Шинкарук, В. (1964). Логика, диалектика и теория познания Гегеля. Киев: Изд-во Киев. ун-та, 44.

2 Шинкарук, В. (1974). Теория познания, логика и диалектика И. Канта. Киев: Наукова думка, 259.
} 
подібного абсолютного духу він не вірив і також категорично заперечував апріорний характер категорій. Він вважав, що категорії виступають результатом людського досвіду; результатом того, що на основі практики формується досвід, спочатку, як практичне пізнання, а, потім, власне, як теоретичне пізнання - але всі ці елементи виступають частиною практично-духовного відношення людини до світу. Суб'єктом пізнання, носієм категоріальної свідомості стає людство в його історичній реальності. Категорії розвиваються лише завдячуючи тому, що люди передають ці категорії з покоління в покоління, поглиблюють своє розуміння їх сенсу. Без цієї культурної традиції передання категорій нічого не могло би відбутися.

$€$ певний парадокс, який визнається Володимиром Шинкаруком, про те, що мислення $€$ результатом і рухом високорозвиненої органічної матерії, але сама по собі ця органічна матерія, тобто мозок, не здатна мислити. Для того, щоб мозок мислив, необхідно навчити його мисленню, надати йому категорії, за допомогою яких може здійснюватися процес мислення. А зробити це може лише людство, шляхом виховання, освіти, самоосвіти. Без такого засвоєння категорій від попередніх поколінь, здатність високоорганізованої матерії до мислення не буде реалізована. Сама по собі здатність до мислення не “прокидається” у високорозвиненій матерії і “автоматично” реалізуватися не може. Вона потребує суспільного духу для того, щоб цю здатність актуалізувати.

3 іншого боку, важливо, що процес мислення не відбувається і без матеріального носія, не протікає десь у “царстві духів”. Мислення потребує енергії людини, іiї особистої участі. Саме по собі мислення задане нам як мислення інших окремих особистостей, що мислили. Відповідно, це царство смислів передали нам не як дещо пасивне (як шелерівське «царство цінностей»), а як активний процес, що є у певних представників людства, у носіїв культури, у наших попередників, який, дійсно, може нами розвиватися і передаватися далі наступним поколінням.

При цьому слід визнати наявність обмеженого історичного апріоризму, адже по відношенню до мислення окремої особистості певні категорії, напрацьовані у результаті попереднього розвитку людства, мають умовно апріорний характер. Особистість приходить у світ, де категорії вже є. Але вони $є$ не у цієї особистості, а вони є у людства як у сукупності окремих особистостей. Для кожної особистості дані категорії як культурно апріорні, але, в дійсності, ці категорії існують тільки тому, що хтось їх у своєму мисленні відтворює, оновлює, переінтерпретовує і передає наступним поколінням. Мислення подібне до вогню, який передається від смолоскипа до смолоскипа. Сам по собі смолоскип не почне горіти i, відповідно, цей вогонь не буде передаватися. Такого типу уявлення дійсно відповідають тогочасній онтології, яку можна назвати реалістичною, оскільки вона не передбачала існування унікальної безсмертної душі; загальної безсмертної душі людства; апріорних знань; передавання цих апріорних знань поза культурним дискурсом, поза культурною традицією і розвитком всього людства.

Володимир Шинкарук піддає критиці намагання Канта вивести категорії із самої структури людського розуму; з того, що у людини наявні види суджень; із особливостей цих суджень і показати ці категорії як певні вічні властивості людської розумності, які існують завжди і всюди, де ця розумність зустрічається. Володимир Шинкарук наголошує, що категорії виникають внаслідок розвитку розумності і їхня кількість значно більша, ніж та, яку мислили собі Кант і Гегель. Ці категорії постають як надбання досвіду людства, внаслідок чого зростає їх чисельність. Всі спроби прив'язати категорії до структури людського мислення і зробити їх загальнообов'язковими, універсальними $€$ хибними. Категорії відкриваються і набувають універсальності в живому історичному, культурному, філософському, науковому розвитку, але ці процеси не $\epsilon$ напередвизначеними, їх протікання не $\epsilon$ гарантованим.

Володимир Шинкарук вважав, що всі спроби Канта і Гуссерля показати категорії як формальний бік мислення, тотожну структуру свідомості людини будь-якої історичної доби не відповідають історії культури та науки. Шинкарук звертає увагу на те, що величезний період історичного розвитку функціонувало міфологічне, а потім релігійне мислення. Для даних різновидів мислення були характерні свої специфічні категорії, але деякі з них згодом набули значення універсальних, філософських, наукових категорій. Вказаний процес проходив поступово. Якщо подивитися на долю таких категорій як “необхідність" чи “випадковість", то все це осмислювалося в культурних і релігійних образах, міфологемах, ідеях. Лише з часом ці категорії набули статусу філософських, а потім наукових категорій.

Таким чином, перед нами розгортається процес, що виглядає закономірним, а його результати постають як, нібито, зумовлені необхідністю. Але, коли цей процес відбувався, ніщо не гарантувало 
ні того, що людство дійде до філософського і наукового рівнів розвитку; ні того, що ці категорії набудуть саме такого вигляду.

Відповідно, у даній філософській позиції відчувається заклик, як у пізнього Гуссерля, до того, щоби цінувати ті смисли і те культурне, філософське, наукове багатство, яке розвинулося досьогодні i $є$ спільним надбанням усього людства; підтримувати його, не давати його зруйнувати тим, хто закликає до торжества ірраціоналізму.

Висновки. Філософським методом для Володимира Шинкарука стала діалектика. У застосуванні до антропології діалектика дозволила показати людину як єдність протилежностей, оскільки в кожній особистості є протистояння та єдність соціального і біологічного, індивідуального i універсального. Прийняття створених попередніми поколіннями сенсів на початку розвитку особистості дозволяє пізніше додавати власні сенси завдяки індивідуальній творчості. Засвоєння і продукування смислів не є формально-логічним, і це підштовхує до розвитку герменевтики. Для діалектики найбільше антропологічні протилежності виявляються у тому, що людське пізнання визнається як єдність формально-логічного та інтуїтивно-гіпотетичного. Функціонування інтуїтивногіпотетичного елементу пізнання та його єдність з формально-логічним фактично виявляються предметом герменевтики.

\section{References:}

1. Kopnin, P. V. (1973). Dialektika kak logika i teoriya poznaniya [Dialectics as logic and the theory of knowledge]. Moscow: Science. [in Russian].

2. Kopnin, P. V. (1973). Dialektika, logika, nauka [Dialectics, logic, science]. Moscow: Science. [in Russian].

3. Shinkaruk, V. I. (1964). Logika, dialektika i teoriya poznaniya Gegelya [Logic, dialectics and Hegel's theory of knowledge]. Kiev: Kiev University Publishing House. [in Russian].

4. Shinkaruk, V. I. (1974). Teoriya poznaniya, logika i dialektika I. Kanta [The theory of knowledge, logic and dialectics of I. Kant]. Kiev: Naukova Dumka. [in Russian].

5. Shinkaruk, V. I. (1977). Yedinstvo dialektiki, logiki i teoriya poznaniya [The unity of dialectics, logic and the theory of knowledge]. Kiev: Naukova Dumka. [in Russian].

6. Tabachkovskyi, V. (2002). U poshukakh vtrachenoho chasu: narysy pro tvorchu spadshchynu ukrayin'kykh filosofiv 60-kh rokiv [In search of unlost time: essays on the creative legacy of Ukrainian philosophers of the sixties]. Kyiv: Parapan [in Ukrainian]. 